\title{
Al-Ghazālī's Heart as a Medium of Light: Illumination and the Soteriological Process
}

\author{
Loumia Ferhat \\ Farouk Jabre Center, American University of Beirut, Beirut, Lebanon \\ loumiaferhat@yahoo.fr
}

\begin{abstract}
This article focuses on the centrality of the heart in al-Ghazālī's (d. 505/1111) thought. More specifically, it shifts the focus from al-Ghazāli's doctrinal position, at stake when he defines the heart — which has already received much attention - to the practical aspect of the heart, namely its role within al-Ghazālī's reformative project. In doing so, it brings to the fore the entanglement between knowledge acquisition, character refinement, and illumination at the end of the soteriological path, that is, the path leading to the soul's salvation. Paying particular attention to the heart as a medium of light, this article seeks to extend the recent interrogation of philosophy as a way of life, expanding philosophy's perceived boundaries in contemporary thought. In al-Ghazālì's writings, the heart serves not only as the essence of man, but also as a synecdoche for the individual, that is, for the very essence of human subjectivity. As a medium of light, through proper training and spiritual practices, the heart becomes the locus of knowledge acquisition, character refinement, and the final conversion of the gaze. Al-Ghazālì's conception of the heart, then, stands at the crossroads of Sufism and philosophy, where a conception of knowledge that is inseparable from ethics and aesthetics emerges. By examining this merging of ethics and aesthetics in al-Ghazālìs thought, this article argues for the significance of aesthetics to al-Ghazālī, despite his ambivalence towards analogies and sense-perception.
\end{abstract}

* I owe a great debt of gratitude to Cyrus Zargar, Shahzad Bashir and Hent de Vries. I would also like to thank George Saliba for graciously hosting me at the Farouk Jabre Center at the American University of Beirut, and the Arab Council for Social Sciences, which funded the year during which I wrote this article. 


\section{Keywords}

Al-Ghazāli - ethics - aesthetics - epistemology - medium - heart - light - dilation character-refinement

\section{الخلاصة}

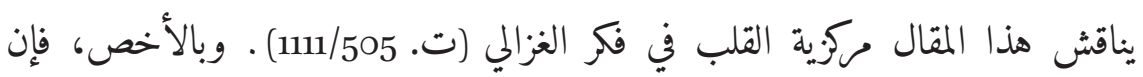

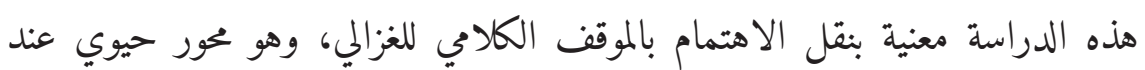
تعريف القلب - هوالذي قد حظي باهتمام كبير بالفعل - إلى الاهتمام بالجانب العملي

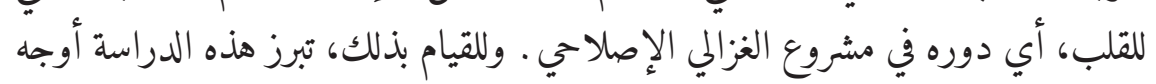

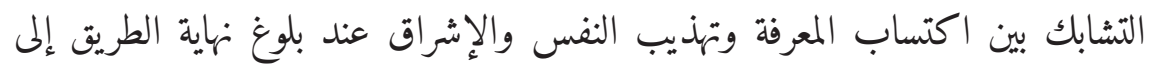

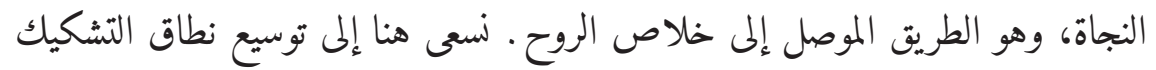

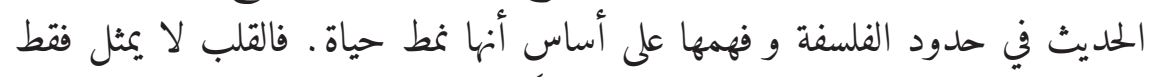

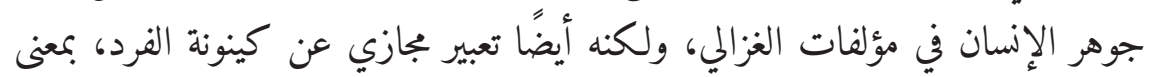

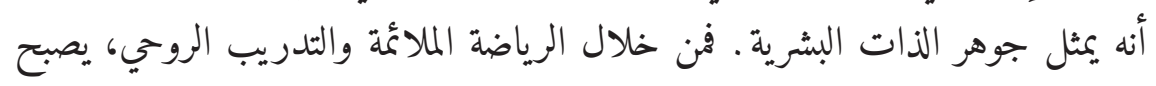
القلب، بوصفه وسيلة نورانية، موضع اكتساب المعرفة وتهذيب النفس ومبتغى البصر

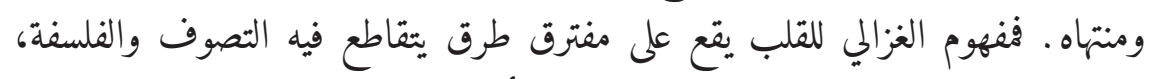

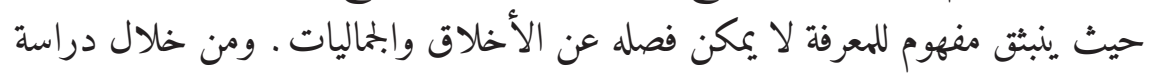

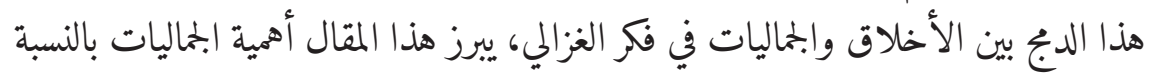

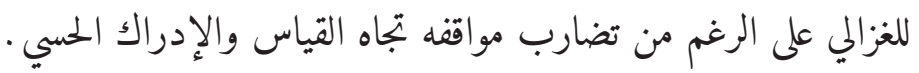

\section{الكلمات المفتاحية}

النفزالي - الأخلاق - الجماليات - نظرية المعرفة - الوسيلة - القلب - النور - التمدد - تهذيب

Once wrongly considered a ferocious opponent to philosophy on account of his Tahäfut al-Falāsifa ("The Incoherence of the Philosophers"), Abū Ḥāmid Muḥammad ibn Muḥammad al-Ghazālī (d. 505/1111) is now acknowledged as 
being greatly indebted to philosophers, even when he points to the limitations of philosophical reasoning (Griffel 2009; Frank 1994). In fact, some scholars now cast al-Ghazālì as a philosopher in disguise, using The Incoherence as a smoke screen, and using his famous autobiography to defend himself in times of political turmoil (Treiger 2011; Garden 2014). What is at stake in qualifying or disqualifying al-Ghazâlī as a philosopher is thus the very definition of philosophy, and the issue of its reduction to theoretical discourses. This is particularly the case when in scholarship on al-Ghazāli both prophecy and the heart are made exclusive to the intellect, despite passages to the contrary in al-Ghazālìs corpus. In order to strip the heart of its emotional connotations, some interpretations of the heart, I argue, have veered too far in the opposite direction. ${ }^{1}$ Such a reading, which turns al-Ghazālī into a crypto-Avicennian thinker, does not seem to take seriously al-Ghazālì's main goal in his magnum opus, Ihyya $\vec{a}^{3}$ 'Ulüm al-Dìn ("The Revival of the Religious Sciences"), namely, to reach salvation, not through intellectual knowledge, but through the implementation of right practices.

Anthropologists and religious studies scholars have been more willing to challenge the modern conception of philosophy as characterised by theoretical discourses. For some, Pierre Hadot's retrieval of philosophy as a way of life and Michel Foucault's focus on the technology of the self have made alternative

1 One major question around the notion of the heart consists in deciding whether the introduction of the heart is mostly a covert way to render a more Islamically palatable counterpart to Avicennian noetics and psychology. Treiger insists that "[i]n calling it heart rather than rational soul or intellect, al-Ghazālì did not intend any radical departure from philosophical noetics in the direction of a more 'emotional' noetics of the heart. He merely intended to defuse the concept's philosophical connotations so as to make it more palatable to the broader circles of religious scholars, while leaving its content essentially the same" (Treiger 2011, 18). Kukkonen is more willing to examine al-Ghazālī's thought as being "representative of a particular moment in the development of Islamic anthropology, one at which the Greek intellectualist ideal as developed by Ibn Sīnā (Avicenna, d. 428/1037) begins to meld with the relentless self-questioning that characterises the moralist strand of Muslim piety" (Kukkonen 2008, 206). Kukkonen is nonetheless considering the heart as being in line with Avicennian psychology, which culminates with the intellect. Commenting on al-Ghazālì's introduction of the term "heart," he adds: "The move represents a strategy common to Ghazâlī's later career, in that he attempts to distance himself from Greek-derived philosophical terminology by putting forward an Arabic-Islamic alternative whenever he can. This should not be allowed to distract from the main issue; Ghazālī's 'pectoral psychology,' to use Ebrahim Moosa's term, is no less a psychology for being pectoral" (Kukkonen 2008, 208). Kukkonen is right in uncovering Ghazali's indebtedness to peripatetic psychology and noetics, but what he sees as a distraction, I see as the focal point of an investigation. As I will highlight further, there is more to the heart than the intellect. 
epistemologies and ethical practices legible in modern academia. ${ }^{2}$ Regardless of the influence of these two thinkers, there has been a renewed interest in the centrality of akhlāq (the refinement of character traits) in philosophy, that is, philosophy as a practical and reformative enterprise. By examining the heart, understood as the essence of the individual, and the practices that surround it, I aim at highlighting the ways in which character refinement leads to salvation and illumination. Rather than trying to identify al-Ghazâlī's true affiliation, this shift of disciplinary boundaries is taken here to reposition the focus on the central role of the heart in al-Ghazālī's soteriology.

This article sets off from the new boundaries set by philosophy as a way of life in order to further bring into this picture the question of aesthetics. It does so by considering the heart, as a medium of light. Given al-Ghazāli's soteriological project, this renegotiation does not happen in the abstract but follows the process leading to salvation. Methodologically, in order to elucidate the mechanisms of the heart I cross check the different metaphors associated with the heart with their ethical equivalent. First, I will start by discussing the nature of the heart's perception, and then answer two interconnected questions: first, how does considering the heart as a porous medium that has to be emptied out and polished in order to be illuminated translate into the terms of the ethical process behind salvation? Second, given that the heart is the essence of man and acts as a synecdoche for the individual, how does the conception of "hollow" subjects influence this process of emptying and refinement, and vice versa? Finally, using the analogy of the medium of light as an organising device, I seek to highlight the connection between knowledge acquisition, character refinement, and the final conversion of the gaze. ${ }^{3}$ Through a focus on the heart - a medium of insight through spiritual exercises—one can appreciate a position at the crossroads of Sufism and philosophy, where a conception of knowledge that is inseparable from ethics and aesthetics emerges.

2 Oludamini Ogunnaike draws from Pierre Hadot's argument of philosophy as a way of life to examine African philosophy but he also applies this concept to Islamic Philosophy by showing how it is in continuity with the primordial conception of philosophy as it originated in Greece, and before it became preoccupied mostly with theoretical discourses (Ogunnaike 2017,187 ). Many scholars of Buddhism have also used Hadot's ideas of spiritual exercises and philosophy as a way of life to reconsider Buddhist texts which may have been studied in the margin of philosophy. See Kapstein $(2013,270)$, Harter $(2018,147)$ and Apple $(2018,105)$.

3 This article results from a dissertation, defended in February 2019, where I followed the subject formation as a thread to question knowledge acquisition and the role of sense perception in al-Ghazālī's corpus. 


\section{The Heart as a Medium of Perception}

\subsection{The Prophecy: Perfection of the Intellect or a Different Faculty?}

I consider the heart for al-Ghazālī as a psychosomatic medium of perception, bypassing the body-soul problem. ${ }^{4}$ Although al-Ghazāli states that the heart is not the same as the physical organ, but is rather the "subtle substance" or the immaterial soul, he also establishes a connection between illumination and the fitness level of the physical heart (al-Ghazālī 1997, 89). As Treiger characterises it, the heart is "the meeting point" of the science of unveiling ( $\mathrm{ilm}$ al-mukāshafa) and the science of practice ('ilm al-mu'āmala) (Treiger 2011, 18). The heart is central to al-Ghazāli's project insofar as it is the essence of man and it is a medium through which illumination, which is also salvation, is reached. In Mishkātal-Anwār ("The Niche of Lights"), his Sufi treatise which for some time was not considered a legitimate al-Ghazâlī text, through the image of illumination al-Ghazāli makes clear the equation between knowledge acquisition, God's disclosure and salvation. The treatise, an interpretation of the hadith of the veils, follows the equivalence between God or the Real, al-haqq (the truth), with the Light, which is to be unveiled at the end of a long process. Al-Munqidh min al-Dalāl ("Deliverer from Error"), his autobiography, also takes up the illumination theme present in the Qur'an by articulating its narrative, and al-Ghazâli's healing, around the verse concerning the heart being dilated and light cast upon it. ${ }^{5} \mathrm{Al}-G$ Gazālī is notoriously not always consistent, but it is fair to assume that the heart "shelters" the intellect without being reduced to it. ${ }^{6}$

In al-Munqidh, al-Ghazāli takes the dream as way of fleshing out a hierarchy between faculties, with these faculties also assuming the role of judge towards lower faculties: sense perception is beneath reason or the intellect, which is itself beneath a faculty associated with a third type of perception. The third faculty after reason - the other "perception" (idrāk), as al-Ghazāli also names it—is triggered by divine illumination. McCarthy translates this

4 The topic has been at the centre of many debates trying to decipher whether al-Ghazālī was aligned with the Ash'arī conception of the soul or with the Avicennian's psychology. On that matter see in particular Gianotti (2001). Rather than trying to intervene in such debates, my article attempts to offer a trajectory which takes the heart as a starting point in order to shift the question from what the heart is to what it can do.

5 Kenneth Garden sees in al-Munqidh merely an attempt by al-Ghazālī to legitimate himself, and does not buy into his moral crisis. For readings that acknowledge the literary construct of al-Munqidh while appreciating its philosophical and theological contribution see Ormsby (1991) and Kukkonen (2010).

6 The intellect acts as a safeguard which validates or invalidates, but it does not give direct access to things. 
as "further perception" (dhalika al-idrāk), while Abūlaylah translates it in this context as "further intelligence" and later, when al-Ghazālī offers a psychological genesis, as another "faculty" (al-Ghazālī 2001, 98). Indeed, the dream example comes back in the second part of the text, when al-Ghazālī offers a proper genesis, where this new "perception" is also referred to as "another eye" ('ayn $u k h r \bar{a}$ ) with the potential to be opened. The seat of this perception, or faculty, is the heart, and, in its capacity as the third faculty it is fundamentally different from the first faculty, the senses, and the second, the intellect. In fact, the restoration of genuine trust in the intellect operates at neither the level of sensory experience nor that of rational thought, but requires God's illumination. al-Ghazālī gives another example in Ihyyä' Ulüm al-Dìn, his magnum opus, which goes in the same direction by distinguishing different degrees of knowledge. The first degree is similar to how one learns from the account of a trustworthy person - a parent or a teacher, for instance- that, for example, someone named Zayd is currently in the house. The second degree of knowledge amounts to hearing the voice of Zayd, who is hidden behind a veil. The third degree of knowledge consists in seeing Zayd with one's own eyes. Here, al-Ghazālì hierarchises knowledge from hearsay, to intellection, and finally to certainty, but it is noteworthy that he puts different kinds of access on different planes. One does not progressively go from hearing about Zayd to seeing him without requiring the use of radically different approaches (al-Ghazāli 2010, 42). There is a leap from hearing behind a veil to seeing with one's own eyes, confirming — if any doubts remained - that in its development prophecy is definitely not in continuity with the intellect.

Yet another example in the Ihyyä plays out through the intensification of a single faculty: sight in the guise of light. Al-Ghazāli explains that one can see Zayd better at the peak of the day than later in the evening when the light is dimmer (al-Ghazāli 2010, 43). If one pays attention then one notices that the increase in sight depends on the amount of external light. It is not the eyes that see better by themselves, but it is the increase of an external light that allows one to see more clearly: in other words, the extent to which one is illuminated. Concretely, for the acquisition of knowledge, one has to incline oneself more or less towards more or less light. Another passage in Mishkāt al-Anwār seems to equate insight (bașira) with the intellect in contradistinction with actual eyesight. Later on, al-Ghazāli makes it clear that this is part of a perceptual hierarchy. In a similar fashion as in al-Munqidh, al-Ghazālī states: "there is another stage beyond the rational faculty ('aql) within which there becomes manifest that which does not become to the rational faculty" (al-Ghazālī 1998, 37). This ultimate stage or faculty remains when the "august glories of His face burn up everything that sensory sight and rational insight (bașira 'aqliyya) are 
able to perceive" (al-Ghazālī 1998, 52). In this text, this is where al-Ghazālī strategically introduces taste (dhawq) and allows it to take over.

In the defence of the position arguing for prophecy being a perfection of the intellect, al-Ghazāli seems to be using two different models: a quantitative increase and a qualitative shift. ${ }^{7}$ This question would require an article by itself, but the reason to opt for a qualitative shift, aside from al-Ghazâli’s explicit position in al-Munqidh, is due to the recurring opposition between different learning approaches, which seems to indicate the use of different faculties. ${ }^{8}$ This article does not purport to give an exhaustive picture of knowledge in al-Ghazālì's corpus. While being aware of al-Ghazālī's at times contradictory positions, I have made some interpretative choices which take al-Ghazālìs leaning toward Sufism at face value..$^{9}$ It seems that although al-Ghazālī inherits a philosophical paradigm that conflates prophecy with the intellect and its visual metaphors, he distances himself from this paradigm by incorporating a Sufi understanding of prophecy, with an emphasis on spiritual practice and the introduction of the notion of taste. Hence, I tend to agree more with Eric Ormsby, who considers prophecy as a spiritualised sense, rather than with Treiger, who calls it intellectual vision. ${ }^{10}$ It seems to me that this third faculty,

7 It seems that Treiger adopts the position that a quantitative increase leads to a qualitative leap when he argues that prophecy is a stage of cognition which is above philosophy and yet not essentially different. Caner Dagli voiced some doubts concerning this very characterisation of dhawq. See Dagli $(2016,38)$.

8 As Treiger highlights, in the Ihyyā al-Ghazālī uses the term "perfection" (istikmāl) and the opposition between rind and pith to describe the different levels of knowledge (Treiger 2012, 50). This seems to be an argument in favour of a "deepening" of the same faculty. For a thorough discussion of the Avicennians' use of "istikmāl" to translate the Aristotelian entelechy, see Wisnovsky (2003). Yet, I am wondering, given al-Ghazāli’s statements concerning faculties, whether the "transcending" that taste would involve should still be understood as a perfection. It seems that dhawq comes to complete intellectual knowledge, rather than being a more developed version of intellectual and philosophical knowledge (Treiger 2012, 51). To use al-Ghazālì's well-known argument, "there is indeed a difference between a sick person's knowledge of health and a healthy person's knowledge of the same." These two types of knowledge complete each other, and the latter requires the implementation of a radically different approach than that of the former, rather than an "internalisation" of it.

9 For a charitable interpretation of al-Ghazālī's contradictory positions see Ormsby (2008) and Kukkonen (2015).

10 There may be an equivocal use of intellect at play here. Many translators of al-Ghazālìs texts have chosen "rational" for "intellectual." I see that choice as a way to narrow down the understanding of the intellect to its logical, discursive nature, and to dissociate it from the intellect in its capacity for intuition (hads). It seems to me that al-Ghazāli departs from Avicenna by limiting the intellect to discursive knowledge and suggests the existence of another faculty. 
prophecy, is the synthesis - understood as a whole greater than its parts-of the senses and the intellect, and as such it has the cognitive power of the intellect and the immediacy of the senses. It is cognitive without being intellectual. Ormsby, rightly, considers that al-Munqidh "is balanced between sets of contrasting pairs of states, or events, or faculties. What misled and deluded him in his unilluminated condition before his collapse later, after his inner turn, becomes an instrument of perception and healing" (Ormsby 1991, 149, my italics). Al-Ghazālī applied such a notion of contrasting pairs of states to taste in particular: taste is both a faculty and a sense-perception, being one of the lowest, most animalistic sense perceptions and yet becoming one of the most spiritual.1 This notion of taste, used by al-Ghazālī interchangeably with prophetic witnessing and unveiling, anchors the prophetic perception within an intimate experience reached through a refinement of character (tahdhib $a l-a k h l \bar{a} q)$ and remembering of God (dhikr). Al-Ghazāli thus introduces the possibility of decoupling the optical and visual metaphors from the intellect to associate it with an epistemology that is ethical insofar as it is supposed to lead to healing, salvation and ideally to happiness.

\subsection{Polished Mirror and Dilated Heart}

Al-Ghazālī illustrates such a holistic process, in contradistinction with knowledge accumulation, through a story staging two different strategies used during a painting contest. The story recounts how a king organised a painting contest to judge between the Chinese and the Byzantines, who were competing with each other over the "beauty of their workmanship in decorating and painting." To the great surprise of the king the Chinese entered the contest without any colour, but when the veil was lifted he realised they had been polishing their side in such a way that it became like "a polished mirror" (al-miräat almajluwwa) and reflected the Byzantine's work with added "illumination and dazzling brilliance" (al-Ghazālì 2010, 61-63). Grasping the nature of the Real, that is, of God, does not consist in accumulating knowledge but in acquiring a good character through a work of cleaning, rectification and polishing.

Although the removing of stains is supposed to be transformative, the "reflection" that ensues seems to happen without a fundamental change in the medium itself. The analogy with a camera-a medium of light—is helpful for

11 The ambivalence of taste can be traced back to the Qur’ān. As Kathryn Kueny writes: "In the garden, taste and what it craves are set at a reflective distance, as paradisiacal bodies are severed from more animalistic urges through a cultivation of elite desires. On earth, taste may be tinged with sweetness, but also with uncertainty, terror and trauma" (Kueny 2019, 20). 
two reasons: it includes the polishing of the heart as a mirror, just as one would also clean the lens of a camera, and its dilation, as with a lens mimicking a pupil, to receive the divine light. How does one have any say in this dilation, given that God is ultimately the one dilating and illuminating? The answer is that one can dispose himself, since that is a "matter of his choice (ikhtiyār)," but "not by his choice, however, can he procure the gift of the mercy of God" (al-Ghazālī 2010, 55). Although one cannot force this illumination, one can dispose oneself towards it by following a set of spiritual exercises. These consist in a gradual process involving temperance, and then a focus gained through asceticism: it is only after closure and isolation that illumination is made possible. In optical terms, dilation leading to the illumination of the heart would occur as a gradual process of accommodation from a narrowly focused and polished medium - the heart understood as the pupil or the lens of a camera.

The difference between these two metaphors is that in one case the act of seeing is operated by someone else, the king, who can see the Real being reflected in the mirror, while with the metaphor of the heart as a medium of light, although God dilates such a medium, it is also conducive to a shift of perception and the production of a form of vision for the practitioner. What I find helpful with the photography analogy is that a picture is a photograph of one's surroundings while also being an indication of one's mastery of the medium and the exposure to the light: the right exposure prevents a picture from being overexposed or underexposed. In short, I am suggesting that for al-Ghazāli the heart being rightly exposed produces a photograph-vision, not only reflecting one's surroundings, but also indicating one's exposure, these two aspects being suggestive of how, for al-Ghazālī, "that which makes manifest cannot be separate from that which is made manifest" (al-Ghazāli 1998, 24). The analogy of the camera is helpful insofar as it ties together the two metaphors al-Ghazāli uses, showing the dynamic process at stake in receiving illumination: the heart as a medium, which like a pupil gets dilated and sees, and the polished mirror that reflects things. It makes explicit the fact that the possibility of "reflecting" the Light, or the Real, as transparently as possible requires not only turning toward the source of light, but also being rightly exposed and learning to master such a medium. ${ }^{12}$ This analogy is thus also a pedagogical tool, as it enables

12 Al-Ghazālī explains that there are five reasons why the heart wouldn't be able to reflect the light: "first, a defect in its formation, as for example, a piece of crude iron before it turned and shaped and polished; second, because of its dirt and rust and dullness, even though it is perfect in formation; third, because it is turned away from the direction of the object toward something else, as, for example, if the object were behind the mirror; fourth, because of ignorance of the direction of the object desired, so that it is impossible to place it in front of the position and direction of the object; and fifth, because of 
one to "see" one's own exposure. Finally, this analogy enables me to bring to the fore the relation between vision and the heart as a medium being exposed to light, that is, being under divine influence. It shows that the possibility to reflect things as they really are, requires the practitioner to empty out her heart and to expose it to the right source of light, in order for it to be properly expanded. Although the heart can never be overexposed to the divine light, it can be exposed improperly, to the wrong influences. The work of the practitioner will then consist in focusing and emptying out the heart-medium, an endless process considering that it is always under attack.

\section{Emptying and Polishing the Heart, or Character Refinement}

\subsection{Al-sharh: Dilation, Dissolution, Inflation}

By reading the heart as a medium of light, I am merely taking al-Ghazāli’s knack for vivid illustrations a step further. My transposition is warranted not only by al-Ghazālì's numerous analogies with light sources and reflective surfaces, but also by his fleshing out, in Mishkāt al-Anwār, of a method of interpretation..$^{13}$ McCarthy's translation of the term sharh as dilation is particularly interesting in this regard, because it retains both, on one hand, the idea of expansion, and, on the other, the optical metaphor of the heart as a third faculty gifted with, once it has been polished, the in-sight (bașira) to see the Real.

Progressivity, that is, the patience not to skip any steps, and the use of the intellect do not secure the proper dilation of the heart, but they prevent the possible inflation of the ego or dissolution of the individual due to overindulgence. I would like to suggest that the inflation of the ego is the contrary to the dilation of the heart rendered as "sharh." It is not clear whether al-Ghazālī had in mind such a contradictory concept of dilation, where it can be considered a kind of dissolution, but it would fit al-Ghazālī's tendency to use contraries and counterparts, as Ormsby has noted of the al-Munqidh, where these can be read as before and after states of al-Ghazālī's famous moral crisis. al-Ghazālī

ignorance of the direction of the object desired, so that it is impossible to place it in front of the position and direction of the object" (al-Ghazālì 2010, 36).

13 In Mishkāt al-Anwār al-Ghazālī explains how similitudes (mithāl) point toward the truth. For instance, when God is compared with the Sun, or the Highest Light, what is at stake is the possibility for God to make everything visible without being visible. If one were to look at the Sun directly, one would be blinded by the strength of light. Such a transposition from God to the optical realm draws attention to one aspect of God's mode of operation. 
mentions this duality explicitly in Mishkāt al-Anwār when he explains that this world and the next world, of which some aspects can be accessed within this one, "are two contraries and counterparts," just as two extremes on the same spectrum resemble each other while being opposite (al-Ghazāli 1998, 30). This may explain why in al-Ghazâli's corpus the same phenomenon, in this case expansion, can often fall into one category, such as illumination, or its contrary, such as moral blindness.

Al-Ghazālì often uses vivid examples to address epistemological questions and ethical concerns in a way that shifts the focus from a moral essentialism to an investigation of the ethical process beyond good and evil. This allows the reader to suspend, for a moment, any moral judgment in order to grasp the mechanisms at stake in ethical pursuits. This is not to say that al-Ghazāli "aestheticises" ethical concern; on the contrary, he re-inscribes these examples within a moral dualism. Following al-Ghazālī's gesture, I would like to suggest, along with the idea of the heart as a medium of light, that the success of the soteriological process can also be read through the optical metaphor, particularly through the idea of dilation and exposure. Al-Ghazâli warns the reader multiple times against the risk of erroneous ideas, which he compares to intoxication. The risk of an artificial dilation would be the equivalent of visual accommodation being disrupted by a shortcut and leading to a broad aperture. Here, again, the parallel with the camera supposedly mimicking the pupil is helpful. Al-Ghazālì does not explicitly oppose a "natural," yet divine, dilation with the self-induced delusion of some mystics, but I propose that the use of the term intoxication (sukr) points toward some kind of, to use a French modernist poetic expression, "artificial paradises."

I use the term artificial not in opposition to natural, since the "artificial" effects of alcohol or drugs are still natural, but to oppose an engineered shortcut to an organic process. The artificial dilation, because there is too much light at once, resolves into temporary blindness or overexposure, similar to when one forces the aperture of a camera. Blindness is often associated with either an internal lack, when the eyesight is flawed, or an external lack, in the case of darkness or too much light. Hence, maintaining the parallel between the pupil and the heart, when the heart is intoxicated, just as we can speak of the pupil being overly and improperly dilated, so can we of the soul. The improper dilation of the pupil that results from intoxication is equivalent, in terms of mechanism, to the porosity of a heart overexposed, via erroneous ideas, to overwhelming influences. This necessitates progressivity, a central notion in al-Ghazäli's comparison of the Sufi path with the education of a young boy. Prophecy could be seen in continuity with philosophical knowledge in terms of pedagogy, but not in terms of epistemology: prophecy is not reached by internalising and 
"deepening" philosophical, discursive knowledge, yet, for most, intellectual knowledge is a required propaedeutic to Sufi practices.

Al-Ghazālī distinguishes between general inspiration (ilhām) or prophetic inspiration (wahy) and learning (tácallum), which involves inferences and the use of proofs. It is quite obvious to start at the beginning, but some impatient travellers might be tempted to skip steps. A happy few are endowed with the capacity to receive general inspiration or prophetic inspiration immediately, but for the vast majority "to busy one's self in the path of learning is a surer and easier means of attaining the aim." Indeed, "[i]f progress in the discipline and improvement of the soul is not made by means of the realities of the sciences, the heart is ensnared with corrupt imaginings in which the soul trusts for a long time before they come to an end" (al-Ghazālī 2010, 56). For al-Ghazālī, imagination is helpful as in the case of analogies and transpositions, but it can also derail the individual when it is not checked by the intellect, which acts mostly as a safeguard. Al-Ghazāli has in mind here those who claim that they do not need to study jurisprudence because the prophet "did not study it and he became one who understood the divine law by means of prophetic and general inspiration" (al-Ghazālī 2010, 56). Although not sufficient to reaching the ultimate kind of knowledge, I see al-Ghazālì's warnings as a way to carve a space for intellectual learning as a necessary safeguard against the delusion that may accompany a spiritual practice when being undertaken too soon and taken to its extreme. ${ }^{14}$ Indeed, the Sufi or gnostic ('ârif) —al-Ghazālī uses both term interchangeably — is always haunted by the risk of delusion, the spiritual equivalent of intoxication. In that case, the Sufi or gnostic can be said to be intoxicated with erroneous ideas. It would be tempting to consider that the problem with al-Ḥāllaj (d. 309/922) and al-Bisțāmī (d. 234/848 or 261/875), for instance, did not reside in the state they entered, but in the very fact they spoke about it. Al-Makkī (d. 386/996), who was an influence on al-Ghazālī, adhered to a sober Sufism which condemned mystical utterances considered as excessive: "the ones who exceed the proper bounds are the ecstatic utterers (shätịh)."15 Al-Ghazāli seems to go in that direction in the Mishkāt al-Anwār when he writes that " $[\mathrm{t}]$ he speech of lovers in the state of intoxication should be concealed and not spread about," but then he clarifies that it is not just their speech which is faulty, but rather their experience. Once intoxication subsides "they come to know that what they experienced was not the reality of

14 The intellect is a sobering antidote to the Sufi who derailed: "When this intoxication subsides, the ruling authority of the rational faculty ('aql) — which is God's balance in His earth—is given back to them" (al-Ghazālī, 1998, 18).

15 See Khalil $(2012,16)$. 
unification but that it was similar to unification" (al-Ghazāli 1998, 18). In that case, the dilation of the heart gave way to the inflation of the ego, where Sufis such as al-Ḥāllaj and al-Bisțāmī believed there was a conjunction or a union with God.

\subsection{Closure of the Self and Immersion in God}

As openness or overexposure can be risky, one should proceed gradually and in order. The practice of sobriety and moderation seems to be at the root of the possibility to achieve correct illumination. Yet one can identify some tensions, mentioned by some commentators, in al-Ghazâli's corpus, such as the temptation of asceticism while adopting the Aristotelian golden mean. This tension also manifests in the counterintuitive nature of the "emptying out" of the heart that concretely consists in learning temperance, and ultimately in refining a character. Indeed, emptying the heart actually refers to practicing temperance, to preventing wrong influences from taking a place within the heart. It is the work of uprooting the attachment to the world by developing a state of detachment.

While the ascetic viewpoint, understood through radical practices, is the crux of the book on the heart in the Ihy $\bar{a}$, in the books on disciplining the soul al-Ghazālì advocates a more moderate approach. ${ }^{16}$ And not only there is a tension between moderation and a form of asceticism which advocates a complete detachment from the world, but, even within the book on the heart, al-Ghazāli acknowledges the difficulty of maintaining a state of the remembrance of God and of illumination for a long period of time. ${ }^{17}$ Illumination is not a permanent state, and it presents itself as a "flash of lightning" that may

16 Leah Kinberg considers zuhd, that we usually translate as asceticism, as being intrinsic to Islam and ideally part of everyday life rather than being merely marked by abstinence or isolation. As Kinberg writes "Since $z$ uhd by no means calls for the desertion of this world, a compromise must be found between the fact that zuhd is directed to the dwellers of this world and the fact that perfection cannot be achieved without ignoring one's physical existence." See Kinberg $(1985,36)$. Zuhd does not have to be identified with isolation, but the latter can be part of it. Zuhd or asceticism can hence be practiced through isolation, but also by being detached within the world.

17 Kukkonen sees in al-Ghazâli's defence of moderation a "defence of metriopatheia as the next best thing to apathy." He writes, "[t]he Aristotelian well-rounded person, we will remember, is one who is suitably impassioned in matters large and small, at the right time, in the right measure. For al-Ghazālī, by contrast, the ideal is the sage whose sole desire is for God, while any detraction from this constitutes a failing of a greater or a lesser magnitude. The virtues are developed as the mean between two extremes because this is what brings us closest to the angels who fell nothing at all towards the world." See Kukkonen $(2015,154)$. 
be extended for a "longer or shorter time" (al-Ghazālī 2010, 55). The tension between devoting one's life to adoring God and honouring the creation mandate by having a family is also not absent from al-Ghazâli's corpus. The endorsement of asceticism is even more intriguing given al-Ghazāli’s understanding that, practically, desire cannot be suppressed — and should not be suppressed, for the sake of personal and species survival. Yet it has to be kept under control (al-Ghazālī 1997, 27). Even more confusing is al-Ghazālī's insistence on a program that clashes with asceticism when he affirms that "what is required is not the total extirpation of these things, but rather the restoration of their balance and moderation (itida $\bar{l}$ ), which is the middle point (wasat $)$ between excess and defect" (al-Ghazālī 1997, 27-28).

In the spiritual register, emptying out allows one to make room for God, but concretely it requires the warding off of demonic influences through moderation. When the appetite is being indulged, it becomes an internal breach that allows demonic suggestions to have a strong influence over the individual. Given the impossibility of uprooting desire once for all, the best strategy is to adopt detachment through moderation, in order to sustain, but not to indulge, the body. This moderation is the first step in developing an indifference toward the world, without the fear of a later need to compensate, or the mental whiplash from swinging between two extremes. As a result, all of the idiosyncratic manifestations of qualities in the line of the appetite that manifest themselves—shamelessness, wickedness, avarice, hypocrisy, and so on-are removed, making room for the seeker to focus on God. The boundaries of the subject are thus being reconfigured: it is not a matter of oneself against others, but what in oneself leads to God and felicity, and what does not. ${ }^{18}$

After moderation restores the good health of the seeker in finding a space between extremes, more strenuous practices such as devotion in isolation are necessary to reach divine illumination. In light of this, seclusion is not only possible, but desirable, if it is reached in the right order. Once detachment within the world has been reached then isolation and the remembrance of God are possible without swinging into another extreme, or into a delusional belief of becoming God. There is a dialectic between the two types of asceticism, the moderate one and the more extreme one: the former acts as a propaedeutic to the second insofar as moderation prevents any derailment within isolation, while isolation implements more strenuous practices which ingrain God's remembrance within the Sufi who can then go back to the world more detached than ever. In short, one needs to empty the heart first, and then

18 Here I am accepting the possibility of attaining felicity (saca da), and not just salvation (najāt), regardless of its difficulty. 
polish it. The practice of emptying is not merely a work of the negative. It is rather a corrective work, which seeks to replace extreme behaviours with moderate behaviours, using the other extreme in order to find the middle ground. After seclusion and God's disclosure, there is no real risk of returning to the pre-illumination state. The closure of the self, or death of the societal self, is necessary for witnessing God's disclosure. Illumination is the result of emptying (tafrigh) the heart by reaching detachment, through moderation, and then polishing (jallā) the heart, achieved through "sit[ting] with an empty heart (färigh al-qalb) and concentrated (majmū) purpose." Going back to the analogy with the medium of light, the openness of the heart to be illuminated properly-neither overexposed, nor underexposed-results from the right aperture of the medium, while also being "concentrated," that is, focused.

\section{Technology of the Heart}

\subsection{Self-Sabotage}

So far, while I have drawn out a parallel between the process of illumination and visual metaphors, I have not yet directly tackled the issue of aesthetics, and in particular its relation to ethics. I would like to address the issue of "aestheticising" ethics, which I could be accused of doing through my aesthetical transposition, via Pierre Hadot's criticism of Michel Foucault's appropriation of spiritual exercises. This also offers the opportunity to address the notion of technology of the self that has emerged in Islamic Studies, to indicate a set of specific techniques aimed at constituting the Muslim self. ${ }^{19}$ Pierre Hadot famously turned to his expertise of ancient philosophy to show how philosophy used to be more concerned with an ethical way of life, rather than theoretical discourses. This expanded conception of philosophy, which according to Hadot consists merely in retrieving the original meaning of the discipline, has been used to include al-Ghazāli and other thinkers among those considered philosophers. The problem occurs when scholars have, alongside this, appropriated Foucault's conception of "technology of the self," which itself is an appropriation of Hadot's spiritual exercises. According to Hadot, Foucault bypassed the spiritual component of spiritual exercises to focus exclusively on the self, hence "propounding a culture of the self which is too aesthetic," or "a new form of Dandyism, late twentieth-century style" (Hadot 1995, 211).

19 See the "Technologies of the Self in Islam" reading group conducted by the department of Religious Studies at the University of Colorado, Mahmood (2004), Moosa $(2005,237)$ and Ames (2016). 
Foucault's reformulation of the spiritual exercises into a technology of the self is hence said to betray the original meaning of these exercises, which was not to solidify the self, but rather to transcend it.

As Hadot affirms, most of the ancients, with the exception of Epicureans, aspired to reach a greater Other, be it the cosmos or nature, in a process of depersonalisation. Hence, against Foucault, the technology of the self would be, if anything, a technology of self-sabotage or, to go back to al-Ghazālì, a technology of the heart that consists in purifying the heart (qalb) from the egoistic tendencies of the self (nafs). Yet in response to this we can say that, first, the real problem with regards to Foucault's position does not lie in the use of different techniques for the self, but in the end goal of the constitution of an autonomous self. And second, the criticism of the aestheticisation of ethics can only hold if aesthetics is a category completely divorced from ethics. This can indeed be the case, notably when one is singling out a technique (techne), which referred to craft or art. In fact, my reading of the heart as a medium, with its subsequent mechanisation, takes advantage of such a divorce in order to displace - temporarily - ethical concerns to an aesthetical ground, with the aim of coming back to them with a new perspective. The technique, in itself, is merely a process of repetition that can be applied to any aim: becoming a calligrapher, or here becoming wise, which consists in acquiring temperance. In itself the technique is not ethical or spiritual, but what makes it a spiritual exercise is its soteriological end goal, which translates into divine illumination.

Such a technology of the heart is actually a self-sabotage insofar as the self is said to often be aligned with demonic influences. Moreover, as Ebrahim Moosa notes, there is, so to speak, no "substratum" in a subject: it is ever changing, "for better or for worse" (Moosa 2005, 227). The choices the individual makes can be read as being in alignment with angels or demons. Being aligned with angels is fed by the remembrance of God and discipline, while being aligned with demons is fed by forgetting God and indulging the "appetence" (al-Ghazāli 2010, 8o-81). Further, there is a proportional relation between angels and demons, such that when the demon is being fed, the angel starves, and when the angels are fed, the demons starve. The individual is then effectively in charge of his or her choices, and can then starve or feed his demons, and thus tame them or become enslaved to them: "But whosoever follows desire is the servant of desire, not a servant of God; therefore, God gives the demon power over him" (al-Ghazāli 2010, 81). Vigilance is relentless, as it is impossible to be rid of negative influences once for all: "for as long as he is alive the gates [from whence] Satan [enters] are open to his heart and cannot be closed" (al-Ghazālī 2010, 
87). What then defines an individual lies more in his or her choices and with which type of influence he or she will align with.

Yet the emptying of the heart does not consist in ceding one's own agency for the sake of another, at least not for another alter-ego. If the recipient of this disempowerment were another person, one would find oneself in the same schizophrenic aphasia al-Ghazālī experienced while adopting the viewpoints of the different schools of thought he encountered. ${ }^{20}$ Here, the disempowerment of oneself is ultimately not for the sake of another, but a wholly different Other. Moreover, in al-Ghazālì's framework it would be absurd to dissolve the ego through emptying the heart only to replace it with an alter-ego, or, worse, a quality such as the demonic. Hence, it is critical that the void made within the heart is not hijacked by a quality that would enslave an individual and preoccupy him with nothing but lust, anger, or appetence. This is why it is necessary to follow the right order, starting with moderation in order to reach a detachment where "the existence of all these is the same of their nonexistence" (al-Ghazāli 2010, 54). Then, one should find a place of retreat (khalwa) to practice the remembrance of God in isolation. The emptying seems to be part of a refinement of character (tahdhïb al-akhlāq) and of making oneself impervious to Satan's whispers by being as detached as possible. It paves the way for the work of polishing the heart, which consists in actively remembering God in such a way that He is reflected in the heart of the practitioner in the purest way.

\subsection{The Real and Realism}

The distinction between two perceptions - the Real one and the one from everyday reality - should not be understood on subjective grounds. In other words, the possibility of seeing the Real is not the result of a modified state of consciousness, but the result of polishing the heart, which can then reflect things as they really are. To follow Joseph Lumbard, "the goal of knowledge is wisdom that derives from a living intelligence that is able to see things as they are "in themselves" (kamā hiya) and is able to realise the proper application of such wisdom on all planes and in all affairs" (Lumbard 2019, 409, my italics). Indeed, the temptation is to take any modified state of consciousness as an indication of the Real, when it could be either an indication of one's own intoxication or of a demonic attempt at misleading. In that case, the derailed Sufi takes his subjective experience, being one with the Real, as being objective. ${ }^{21}$ Although the possibility to "see" things as they really are entails

\footnotetext{
20 See al-Ghazālī (2000).

21 See Treiger $(2007,6)$.
} 
an intimate, singular experience, it nonetheless points to a divine truth. Yet, the Real is not the equivalent of everyday realism either. In the example of the contest between the Chinese and the Byzantines, al-Ghazâli indicates that the Chinese were able to reflect the Real (al-haqq) in the most dazzling way. The heart being a mirror to polish, one understands that the Real is not reflected realistically by simply reflecting the perceptions of everyday life, but rather by doing the necessary work to see things not as they appear, but as they really are.

The transposition to photography, due to its apparently easy mechanism, highlights the naïve attempt to capture the Real by merely reproducing it with a click. Snapping a so-called realistic photograph of one's surroundings will produce anything but a satisfactory photograph of the "Real," and it will not even be close to what someone saw with her own eyes. While what the Chinese mirror adds to the painting shows the gap between one's perception and the improvement of such a perception through a device or a technique, photography shows such a gap even more. How many of us have grabbed a camera and clicked, only to be highly disappointed with the result? Yet no one would pretend to be a good painter without first acquiring technique. Photography's apparent easiness is deceptive, but it also highlights the difference between what we see in the moment and the result in the picture. In other words, it could allow us to see the difference between the Real and what we would usually call reality. In such a case, the photograph would not show elements of the real, but allows us to "see," or, rather, would give an approximation of the artist's vision, so to speak. Such a vision is not the vision of God, the Real, but its best approximation. When referring to "having a vision," what is being hinted at is not the activity of sense-perception, but rather the capacity to grasp a meaningful whole as being unified, and a certain disposition toward the world. ${ }^{22}$ Learning to grasp things as they really are is equally about the reality of things as it is about making sure that one is equipped for such a task.

22 The irony of resorting to yet another visual analogy while bringing to the fore the inadequacy of vision, and the subsequent introduction of taste as a result, is not lost on me. Moreover, al-Ghazāli states multiple time that "the wonders of the heart are outside the realm of things perceived through the senses," but he is willing to explain this matter by means of two examples for "people of weak understandings" (al-Ghazālī 2010, 57). I am neither volunteering for the insult, nor am I including my readers in such a category. Rather, by looking at what al-Ghazālī does and not just what he says, I hope to be offering another very imperfect "pointer" towards what could, according to him, only be experienced by closing books and putting articles aside. On a slightly different but related note, see Zargar's Polished Mirror (2017) for a discussion of philosophers' ambivalence towards imagination and storytelling, including the relation between muthos and logos. 
Such a vision is mentioned as the final tawhìd described in Mishkāt al-Anwār, where al-Ghazāli recounts the ascent of the Sufis until the meaning of the Qur'ānic words "Everything is perishing except His face" (Q 28:88), "becomes for them a taste and a state" (al-Ghazālī 1998, 52). What al-Ghazālī means here is that their relation to God is experiential and perceptual. It is not merely a question of subjective perception, as the veils have been lifted and the Sufi is able to see things as they really are, namely as signs of the Creator. The perceptual shift going from sight to taste is also crucial, particularly for an examination of aesthetics, but such an elucidation would require an article in itself. Suffice to say for now that al-Ghazālī uses an abundantly visual vocabulary to refer to the divine experience, but ultimately he switches to taste for the ineffable character of such an experience. Taste here indicates a faculty beyond the intellect that is both subjective, insofar as taste is the most intimate sense-perception, and objective, insofar as it enables one to experience the divine. The completion at stake with the advent of this third faculty implies the possibility of turning the flashing and short spiritual vision into a disposition. When al-Ghazālī refers to character, the other name for a disposition, he demonstrates how it can become engrained: if one wants to become wise, one has to imitate the wise and dedicate a long period of time to devotion and the remembrance of God. While this can be done, one of the remaining hurdles on the path lies in the nature of the "illumination" experienced by the Sufi. Al-Ghazālī insists on describing such an achievement as a "state" (hâal), which is known for being transient. As illumination presents itself in passing flashes, as fleeting states, it is hard to turn it into a long-lasting disposition. Yet, al-Ghazāli seems to suggest that if someone wants to become a sage, he only has to imitate the sage for a long period of time. As Miskawayh puts it: "Theoretical philosophy has made clear that those qualities of the soul quick to disappear are states $(h \bar{a} l)$, and those slow to disappear are dispositions ( $m a l$ $a k a$ )" (see Zargar 2017, 89). This time, the difficulty of becoming wise lies in the possibility of dedicating a long period of time to remembrance, once the heart has been emptied of all the "blameworthy qualities" (al-Ghazālī 2010, 104). Notwithstanding its difficulty, it can be achieved.

As the term aesthetics originally refers to sensory perception, attending to the shift of perception yielded by ethical improvement highlights that, instead of an aestheticisation of ethics, ethics is a matter of aesthetics as well. Aesthetics is in fact central to al-Ghazālì's corpus. Aside from his prolific use of metaphors, the access to the Real is described in terms of a perceptual shift. Ironically, Hadot himself implements such a conception of aesthetics when he considers the result of the spiritual exercises to be a conversion of the gaze, where the practitioner "sees the universe with new eyes, as if he were seeing it 
for the first time. In the enjoyment of the pure present he discovers the mystery and splendor of existence" (Hadot 1995, 212). It seems that when Hadot criticises Foucault for being too aesthetical, he is exclusively using a conception of aesthetics that is divorced from ethics, and in that sense, modern.

By taking the heart as a medium of light to investigate the soteriological process in al-Ghazālī, I have offered a reading where ethical reformation is understood through divine illumination and visual dilation. First, I have highlighted the necessity of temperance, and progressivity, in reaching detachment from the world followed by more strenuous practices in order to ingrain God's remembrance. Hence if emptying out the heart consists in refining the character and finding temperance, this results in a heart which is ready to be polished, namely which can focus solely on God without running the risk of being hijacked by demonic influences. It is only at the end of such a process that the practitioner may experience illumination through God dilating her heart. Such a proper dilation and subsequent illumination is shadowed by a potential inflation of the ego when the room made for God is otherwise derailed by demonic influences and erroneous ideas. I have read the necessity for temperance and progressivity along the visual accommodation and the necessity to focus in order to see things as clearly as possible. Hence, the soteriological process amounts to the proper exposure to the divine light, while taking a shortcut may lead to blindness and overexposure to erroneous ideas. Finally, if the visual vocabulary is fundamentally ethical insofar as it indicates the end goal of the soteriological process, I have showed that ethical reformation can be read as a conversion of the gaze, not only because one can see things as they really are but also because truth manifests itself as a shift of perception.

\section{Bibliography}

Ames, Robert Landau. 2016. "Technology of Happiness: Philosophy, the Body and Ghazāli’s Kìmīyā-yi Sa'ādat." Comparative Islamic Studies 9(2): 121-139. Doi: 10.1558/ cis.vgi2.27043.

Apple, James B. 2018. "The Spiritual Exercises of the Middle Way: Reading Atiśa's Madhyamakopadeśa with Hadot." In Buddhist Spiritual Practices: Thinking with Pierre Hadot on Buddhism, Philosophy, and the Path, edited by David V. Fiordalis, 105-144. Berkeley: Mangalam Press. 
Dagli, Caner. 2016. Ibn al-Arabī and Islamic Intellectual Culture: from Mysticism to Philosophy. New York: Routledge.

Frank, Richard. 1994. Al-Ghazālì and the Ash'arite School. Durham: Duke University Press.

Garden, Kenneth. 2014. The First Islamic Reviver: Abū Hāmid Al-Ghazālè and His Revival of the Religious Sciences. Oxford: Oxford University Press.

al-Ghazālī, Abū Hāmid Muḥammad. 1997. Disciplining the Soul and Breaking the Two Desires: Books XXII and XXIII of the Revival of the Religious Sciences, translated by T. J. Winter. Cambridge: Islamic Texts Society.

al-Ghazālī, Abū Ḥāmid Muhammad. 1998. The Niche of Lights, translated by David Buchman. Provo, Utah: Brigham Young University.

al-Ghazālī, Abū Hāamid Muḥammad. 200o. Deliverance from Error, translated by R. J. McCarthy, 2nd ed. Louisville: Fons Vitae.

al-Ghazālī, Abū Ḥāmid Muhammad. 2001. Deliverance from Error and Mystical Union with the Almighty: Al-Munqidh min al-Daläl, translated by Muhammad Abūlaylah and critical text established by Nurshïf Abdul-Rahīm Rif'at, introduction and notes by George F. McLean. Washington D.C.: Council for Research in Values and Philosophy.

al-Ghazālī, Abū Hāmid Muhammad. 2010. The Marvels of the Heart: Science of the Spirit: Book XXI of the Revival of the Religious Sciences, translated by Walter James Skellie, foreword by T. J. Winter. Louisville: Fons Vitae.

al-Ghazālī, Abū Hāamid Muhammad. 2013. Faith in Divine Unity and Trust in Divine Providence: Book XXXV of the Revival of the Religious Sciences, translated by David Burell, 3rd ed. Louisville: Fons Vitae.

Gianotti, Timothy. 2001. Al-Ghazālı̀'s Unspeakable Doctrine of the Soul: Unveiling the Esoteric Psychology and Eschatology of the Ihyä. Leiden: Brill.

Griffel, Frank. 2009. Al-Ghazālı’s Philosophical Theology. Oxford: Oxford University Press.

Hadot, Pierre. 1995. Philosophy as a Way of Life: Spiritual Exercises from Socrates to Foucault. Hoboken: Wiley-Blackwell.

Harter, Pierre-Julien. 2018. "Spiritual Exercises and the Buddhist Path: an Exercise in Thinking with and against Hadot." In Buddhist Spiritual Practices: Thinking with Pierre Hadot on Buddhism, Philosophy, and the Path, edited by David V. Fiordalis, 146-179. Berkeley: Mangalam Press.

Kapstein, Matthew T. 2013. "Stoics and Bodhisattvas: Spiritual Exercise and Faith in Two Philosophical Traditions.” In Philosophy as a way of Life: Ancient and ModernsEssays in Honor of Pierre Hadot, edited by Michael Chase, Stephen R. L. Clark and Michael McGhee, 99-115. Hoboken NJ: Wiley Blackwell.

Khalil, Atif. 2012. "Abū Țālib al-Makkī \& the Nourishment of Hearts (Qūt al-Qulūb) in the Context of Early Sufism." The Muslim World 102(2): 1-22. 
Kinberg, Leah. 1985. "What is Meant by Zuhd." Studia Islamica 61: 27-44.

Kueny, Kathryn. 2019. "Tasting Fire: Affective Turn in Quranic Depictions of Divine Punishment." Body And Religion 3(1): $5^{-26}$. Doi: 10.1558/bar.16118.

Kukkonen, Taneli. 2008. "The Self as Enemy, the Self as Divine." In Ancient Philosophy of the Self, edited by P. Remes and J. Shilova, 205-224. Dordrecht: Springer Verlag.

Kukkonen, Taneli. 2010. "Al-Ghazālì's Skepticism Revisited." In Rethinking the History of Skepticism: The Missing Medieval Background, edited by Erik Lagerlund, 103-129. Leiden: Brill.

Kukkonen, Taneli. 2015. "Al-Ghazālī on the Emotions." In Islam and Rationality. The Impact of al-Ghazālī, vol. 1, edited by Georges Tamer, 138-164. Leiden: Brill.

Lumbard, Joseph. 2019. "Abū Ḥāmid al-Ghazālī and the Art of Knowing." In Light upon Light: Essays in Islamic Thought and History in Honor of Gerhard Bowering, edited by Jamal J. Elias and Bilal Orfali, 401-419. Leiden: Brill.

Mahmood, Saba. 2004. Politics of Piety: The Islamic Revival and the Feminist Subject. Princeton: Princeton University Press.

Moosa, Ebrahim. 2005. Ghazālē and the Poetics of Imagination. Chapel Hill: University of North Carolina Press.

Ogunnaike, Oludamini. 2017. "African Philosophy Reconsidered: Africa, Religion, Race and Philosophy." Journal of Africana Religions 5(2): 181-216.

Ormsby, Eric. 1991. "The Taste of Truth: The Structure of Experience in Al-Ghazāli’s Al-Munqidh Min al-Daläl." In Islamic Studies Presented to Charles Adams, edited by Wael B. Hallaq and Donald P. Little. 133-152. Leiden: Brill.

Ormsby, Eric. 2008. Ghazali: The Revival of Islam. Oxford: Oneworld Academic.

Treiger, Alexander. 2007. "Monism and Monotheism in al-Ghazālì's Mishkāt al-Anwār." Journal of Qur'anic Studies 9(1): 1-27.

Treiger, Alexander. 2011. Inspired Knowledge in Islamic Thought: Al-Ghazālı’s Theory of Mystical Cognition and its Avicennian Foundation. New York: Routledge.

Treiger, Alexander. 2019. "Al-Ghazālīs Philosophical Soteriology." In Light upon Light: Essays in Islamic Thought and History in Honor of Gerhard Bowering, edited by Jamal J. Elias and Bilal Orfali, 383-40o. Leiden: Brill.

Wisnovsky, Robert. 2003. Avicenna's Metaphysics in Context. Ithaca: Cornell University Press.

Zargar, Cyrus. 2017. The Polished Mirror, Storytelling and the Pursuit of Virtue in Islamic Philosophy and Sufism. London: Oneworld Publications. 